\title{
Supplemental Complement Component C9 Enhances the Capacity of Neonatal Serum to Kill Multiple Isolates of Pathogenic Escherichia coli
}

\author{
HERBERT A. LASSITER, JESSICA L. WILSON, RICHARD C. FELDHOFF, JOHN M. HOFFPAUIR, AND \\ KATHLEEN M. KLUEBER
}

Division of Neonatology, Department of Pediatrics [H.A.L., J.L.W.J, the Department of Anatomical Sciences and Neurobiology [J.M.H., K.M.K.], and the Department of Biochemistry /R.C.F.], University of Louisville School of Medicine, Louisville, Kentucky 40292

\begin{abstract}
Previous studies demonstrated that, compared with adult serum, neonatal serum contained a diminished concentration of complement component $\mathrm{C} 9$ and that supplemental C9 enhanced the capacity of neonatal serum to kill an isolate of Escherichia coli. Therefore, experiments were designed to determine the mechanisms by which supplemental $\mathrm{C} 9$ enhances the bactericidal capacity of neonatal serum and to determine whether supplemental C9 enhances the capacity of neonatal serum to kill several different pathogenic strains of $\boldsymbol{E}$. coli. A radiobinding assay and immunogold electron microscopy using a monoclonal anti-C9 antibody revealed that, compared with $40 \%$ adult serum, neonatal serum deposited a diminished quantity of C9 onto E. coli O7w:K1:NM. Supplemental C9 $(75 \mathrm{mg} / \mathrm{L})$ significantly enhanced the quantity of $\mathrm{C} 9$ deposited by the neonatal serum. Treatment with $10 \mathrm{mM}$ MgEGTA (a mixture of $100 \mathrm{mM} \mathrm{MgCl}$ and $100 \mathrm{mM}$ EGTA that blocks activation of the classic complement pathway but leaves the alternative pathway intact) abolished the capacity of neonatal serum to deposit $C 9$ and to kill the bacteria. Supplemental C9 enhanced the capacity of neonatal serum to kill eight different blood isolates of $E$. coli. Therefore, supplemental $C 9$ enhanced the capacity of neonatal serum to kill $E$. coli by increasing the total quantity of $C 9$ deposited via activation of the classic complement pathway. Neonatal serum contained sufficient quantities of classic pathway components, other than $\mathrm{C9}$, to deposit the supplemental $C 9$ onto $E$. coli and to enhance bacterial killing. The bactericidal activity of neonatal serum against multiple isolates of pathogenic $\boldsymbol{E}$. coli was increased after $\mathbf{C}$ supplementation. We speculate that $C 9$ deficiency may be one of the defects in antibacterial host defense that predisposes neonates to the acquisition of $E$. coli sepsis. (Pediatr Res 35: 389-396, 1994)
\end{abstract}

\section{Abbreviations}

MgEGTA, $100 \mathrm{mM} \mathrm{MgCl}_{2}$ and $100 \mathrm{mM}$ EGTA

$\mathrm{LC}_{90}$, minimum concentration of adult serum required to kill $90 \%$ of an isolate of Escherichia coli during $90 \mathrm{~min}$ of incubation

Received June 1, 1993; accepted November 19, 1993.

Correspondence and reprint requests: Herbert A. Lassiter, M.D., Division of Neonatology, Department of Pediatrics. University of Louisville School of Medicine, Louisville, KY 40292.

Supported by grants from the Division of Neonatology, Department of Pediatrics, University of Louisville School of Medicine, and the Alliant Community Trus Fund, Louisville, Kentucky.

'Presented in part at the $61 \mathrm{st}$ annual meeting of the Society for Pediatric Research, Baltimore, MD, May 1992 and at the 62nd annual meeting of the Society for Pediatric Research, Washington, DC, May 1993.
BPBS $^{+}$, PBS with $1 \mathrm{mM} \mathrm{MgCl}_{2}$ and $0.5 \%$ BSA

BPBS $^{++}$, PBS with $1 \mathrm{mM} \mathrm{MgCl}_{2}, 0.5 \% \mathrm{BSA}$, and 0.15 $\mathrm{mM} \mathrm{CaCl}$

Escherichia coli is the second most common bacterium isolated from the blood of septic neonates $(1,2)$. Newborn infants acquire $E$. coli sepsis for reasons that are not completely understood. In the adult host, complement-mediated cytolysis (bacteriolysis) has been proposed as a mechanism of defense against invasion by gram-negative bacteria (3-5). However, compared with serum from adults, serum from human neonates kills $E$. coli inefficiently $(6,7)$. The ninth component of complement (C9) is a circulating glycoprotein that is required for efficient complement-mediated cytolysis of $E$. coli $(8-10)$. The concentration of C9 is diminished in the sera of human neonates $(11,12)$. Moreover, supplemental C 9 enhanced the capacity of sera from newborn infants to kill a pathogenic isolate of $E$. coli (12).

The mechanism by which supplemental C 9 increases the bactericidal capacity of neonatal serum is not known. Also, whether supplemental C9 affects the bactericidal activity of neonatal serum against other isolates of $E$. coli is not known. Therefore, experiments were designed to determine the effect of supplemental C9 on the kinetics of bacterial killing by neonatal serum, the deposition of $\mathrm{C} 9$ onto the surface of $E$. coli, and the capacity of neonatal serum to kill several different isolates of pathogenic E. coli.

\section{MATERIALS AND METHODS}

Buffers and reagents. The following buffers and reagents were used: Dulbecco PBS (Media Tech, Washington, DC), pH 7.4; BPBS $^{+}$; PPBS $^{++}$; 100 mM MgEGTA (Sigma, St. Louis, MO), pH 7.4; and tryptic soy broth (Difco Laboratories, Detroit, MI). Buffers used in the radiobinding assays and the immunogold assays contained $0.02 \%$ sodium azide (Sigma). Buffers used in the bactericidal assays contained no bacteriostatic agents.

Bacteria. Eight isolates of $E$. coli were obtained from the blood of eight septic neonates who were patients at the Neonatal Intensive Care Unit of Kosair Children's Hospital, Louisville, $\mathrm{KY}$. The serotype of each organism was determined at the $E$. coli Reference Center of Pennsylvania State University, University Park, PA (Table 1). The bacteria were grown overnight and stored in $5-\mathrm{mL}$ aliquots of tryptic soy broth at $-70^{\circ} \mathrm{C}$. Before an experiment, $35 \mathrm{~mL}$ of fresh broth were added, and the bacteria were incubated at $37^{\circ} \mathrm{C}$ for 3 to $4 \mathrm{~h}$ to bring the organisms to $\log$ phase. The bacteria were then washed three times in $\mathrm{BPBS}^{++}$or $\mathrm{BPBS}^{+}$and adjusted by absorbance at $600 \mathrm{~nm}$ to a concentration 
Table 1. Characteristics of E. coli isolates*

\begin{tabular}{ccl}
\hline Isolate & $\mathrm{LC}_{90}(\%)$ & \multicolumn{1}{c}{ Serotype } \\
\hline 1 & 20 & $\mathrm{O} 7 \mathrm{w}: \mathrm{K} 1: \mathrm{NM}$ \\
2 & 30 & $\mathrm{O}(-): \mathrm{H}(-)$ \\
3 & 40 & $\mathrm{O} 7 \mathrm{w}: \mathrm{K} 1: 8 \mathrm{w}$ \\
4 & 60 & $\mathrm{O}(-): \mathrm{K} 1: \mathrm{H}(-)$ \\
5 & 30 & $\mathrm{O} 1: \mathrm{K} 1: \mathrm{NM}$ \\
6 & 30 & $\mathrm{O}(-): \mathrm{K} 1: \mathrm{NM}$ \\
7 & 40 & $\mathrm{O}(-): \mathrm{H}(-)$ \\
8 & 50 & $\mathrm{O} 7: \mathrm{K} 1: \mathrm{NM}$ \\
\hline
\end{tabular}

* Each isolate was obtained from the blood of a septic neonate.

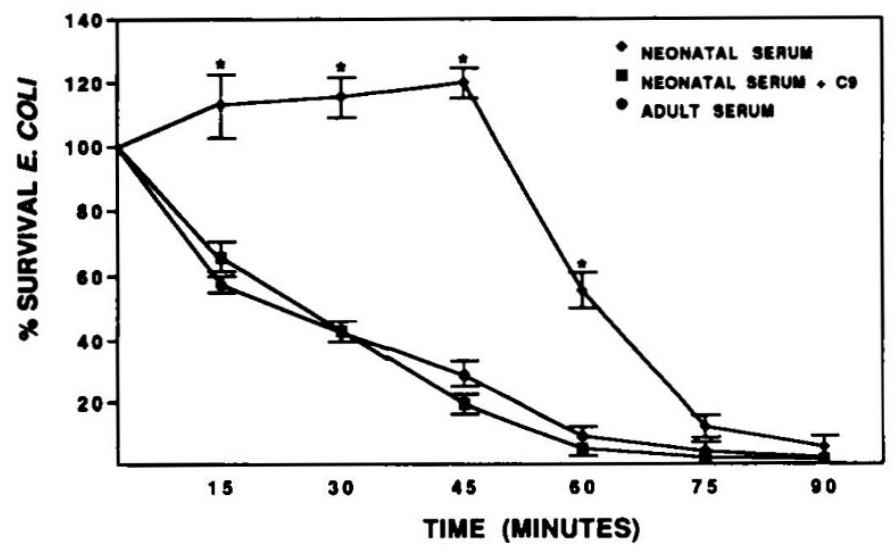

Fig. 1. Effect of supplemental C9 on the bactericidal activity of neonatal serum. $E$. coli $\mathrm{O} 7 \mathrm{w}: \mathrm{K} 1: \mathrm{NM}$ were incubated in pooled neonatal serum (diamonds), pooled neonatal serum supplemented with $\mathrm{C} 9$ (squares), and pooled adult serum (circles). As determined by bactericidal assay, the values are depicted as the mean bacterial survival $\pm \mathrm{SE} .^{*}, p<$ 0.05 vs adult serum and $p<0.05$ vs C9-supplemented neonatal serum. The onset of bacterial killing was delayed in neonatal serum compared with adult serum. However, in neonatal serum, supplemental $\mathrm{C} 9$ accelerated the onset of bacterial killing.

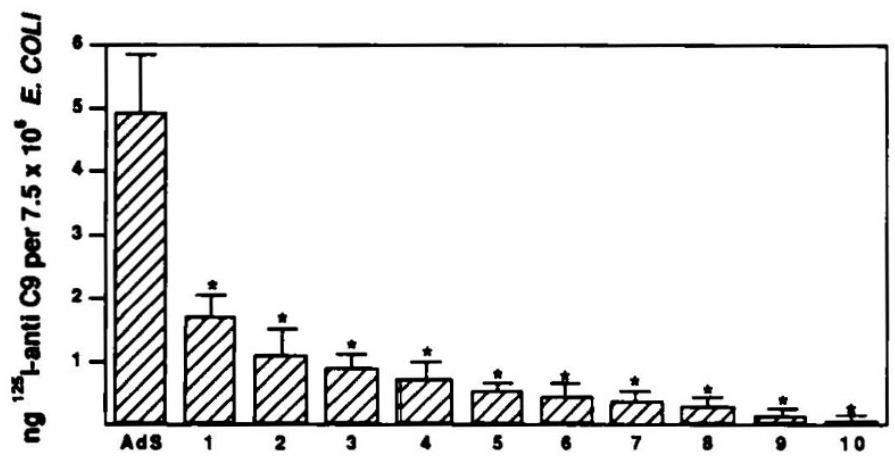

Fig. 2. Deposition of $\mathrm{C} 9$ onto $E$. coli by neonatal sera. $E$. coli 07w:K1:NM were incubated with pooled adult serum $(A d S)$ and with sera from 10 healthy neonates (numbers $1-10$ ). As determined by radiobinding assay, the results are depicted as the mean $(+\mathrm{SE})$ quantity of ${ }^{125}$ I-labeled anti-C 9 antibodies specifically bound to the bacteria $(n=4)$. $*, p<0.01 v s$ adult serum. Compared with adult serum, the neonatal sera deposited C9 onto $E$. coli inefficiently.

of $8 \times 10^{5}$ or $4 \times 10^{9}$ colony forming units $/ \mathrm{mL}$. The concentration of organisms was confirmed by quantitative culture.

Serum. Neonatal sera were obtained from the cord blood of 20 healthy full-term neonates who were delivered vaginally or by elective Cesarean section between July 2 and July 7, 1991, at Norton Hospital, Louisville, KY. The cord blood was obtained by sterile needle puncture of the umbilical vein of the placenta.

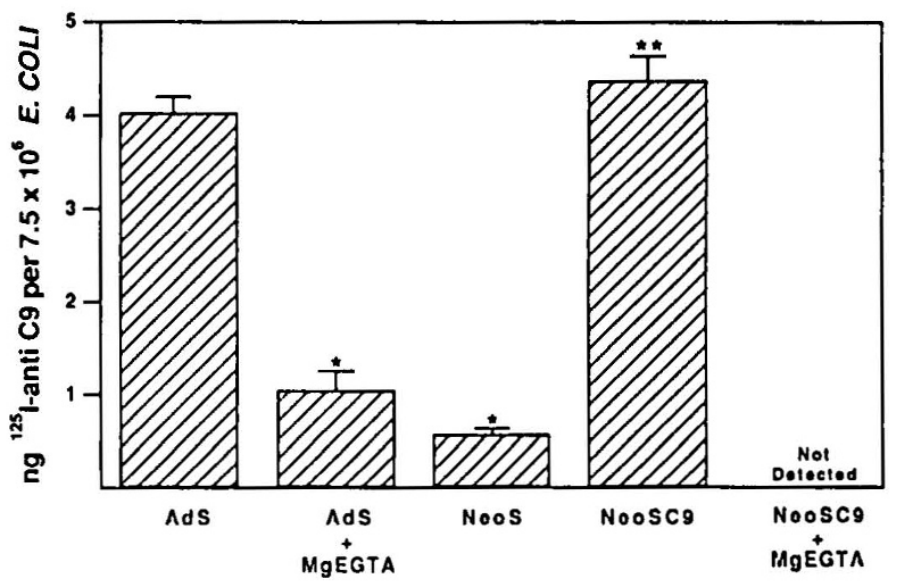

Fig. 3. Effect of supplemental $\mathrm{C} 9$ on the deposition of $\mathrm{C} 9$ onto $E$. coli by neonatal serum. E. coli $\mathrm{O} 7 \mathrm{w}: \mathrm{K} 1: \mathrm{NM}$ were incubated with pooled adult serum $(A d S)$, AdS treated with MgEGTA, pooled neonatal serum (NeoS), NeoS supplemented with C9 (NeoSC9), and C9-supplemented NeoS treated with MgEGTA. As determined by radiobinding assay, the results are depicted as the mean $(+\mathrm{SE})$ quantity of ${ }^{125}$-labeled anti-C9 antibodies specifically bound to the bacteria $(n=3){ }^{*}, p<0.01 v s$ adult serum; ${ }^{* *}, p<0.01$ vs pooled neonatal serum. C9 deposition onto $E$. coli, mediated by the classic complement pathway, was inefficient in the pooled neonatal serum but was enhanced by supplemental $\mathrm{C} 9$.

The serum from each neonate contained less than $0.1 \mathrm{~g} / \mathrm{L}$ of IgA and less than $0.2 \mathrm{~g} / \mathrm{L}$ of IgM, as determined by single radial immunodiffusion (Endplate IgA and Endplate IgM, Kallestad, Austin, TX) (13). Most experiments used serum that was pooled from the blood of the 20 neonates. Sera were also obtained and pooled from five healthy adult volunteers. The serum was separated from the clotted blood by centrifugation and passed through a $0.2-\mu \mathrm{m}$ filter to ensure the removal of bacterial contaminants. Individual sera and the pooled serum were stored at $-70^{\circ} \mathrm{C}$ in sterile vials.

Complement component C9. Purified C9 (Lot no. A40TT23901) was purchased from Quidel Corporation (San Diego, CA) as a solution containing $1000 \mu \mathrm{g}$ of $\mathrm{C} 9 / \mathrm{mL}$ of PBS without bacteriostatic agents. This $\mathrm{C} 9$ preparation was isolated by the method of Biesecker and Müller-Eberhard (14) and was subjected by the manufacturer to an antiimpurities solid-phase immunoaffinity column containing the $\mathrm{IgG}$ fraction isolated from monospecific goat antihuman $\mathrm{C} 3,-\mathrm{C} 5,-\mathrm{C} 6,-\mathrm{C} 7$, and $-\mathrm{C} 8$ to insure the complete removal of these complement proteins. SDS-PAGE and hemolytic assays by the manufacturer demonstrated that more than $95 \%$ of the protein in the solution was pure $\mathrm{C} 9$ and that the solution was completely free of $\mathrm{C} 3, \mathrm{C} 5, \mathrm{C} 6$, $\mathrm{C} 7$, and $\mathrm{C} 8$ functional activities.

To confirm the purity of the C9 preparation used in these studies, various assays were also performed in our laboratory. By nephelometry (Beckman Array Protein System, Beckman Instruments, Brea, CA), the solution did not contain detectable IgA, IgM, or IgG. Because neonatal serum normally contains diminished concentrations of various complement components, such as $\mathrm{C} 3$ and $\mathrm{C} 5$, assays were performed to determine the amount of these two proteins in the $\mathrm{C} 9$ preparation used to supplement the neonatal serum. By radial immunodiffusion using Human C3 NL-RID and Human C5 NL-RID Kits obtained from The Binding Site (San Diego, CA), the C3 and C5 concentrations in the pooled neonatal serum were $977 \mathrm{mg} / \mathrm{L}$ and $124.3 \mathrm{mg} / \mathrm{L}$, respectively, compared with $1149 \mathrm{mg} / \mathrm{L}$ and $149.3 \mathrm{mg} / \mathrm{L}$ in the adult serum. The $C 9$ preparation was subjected to Western-blot analysis (15) using 1 ) rabbit antisera specific for C3, C5, and C9 (Harlan Bioproducts, Indianapolis, IN) and 2) affinity purified antirabbit IgG that had been absorbed with human serum proteins and coupled to alkaline phosphatase (Sigma). Trace 


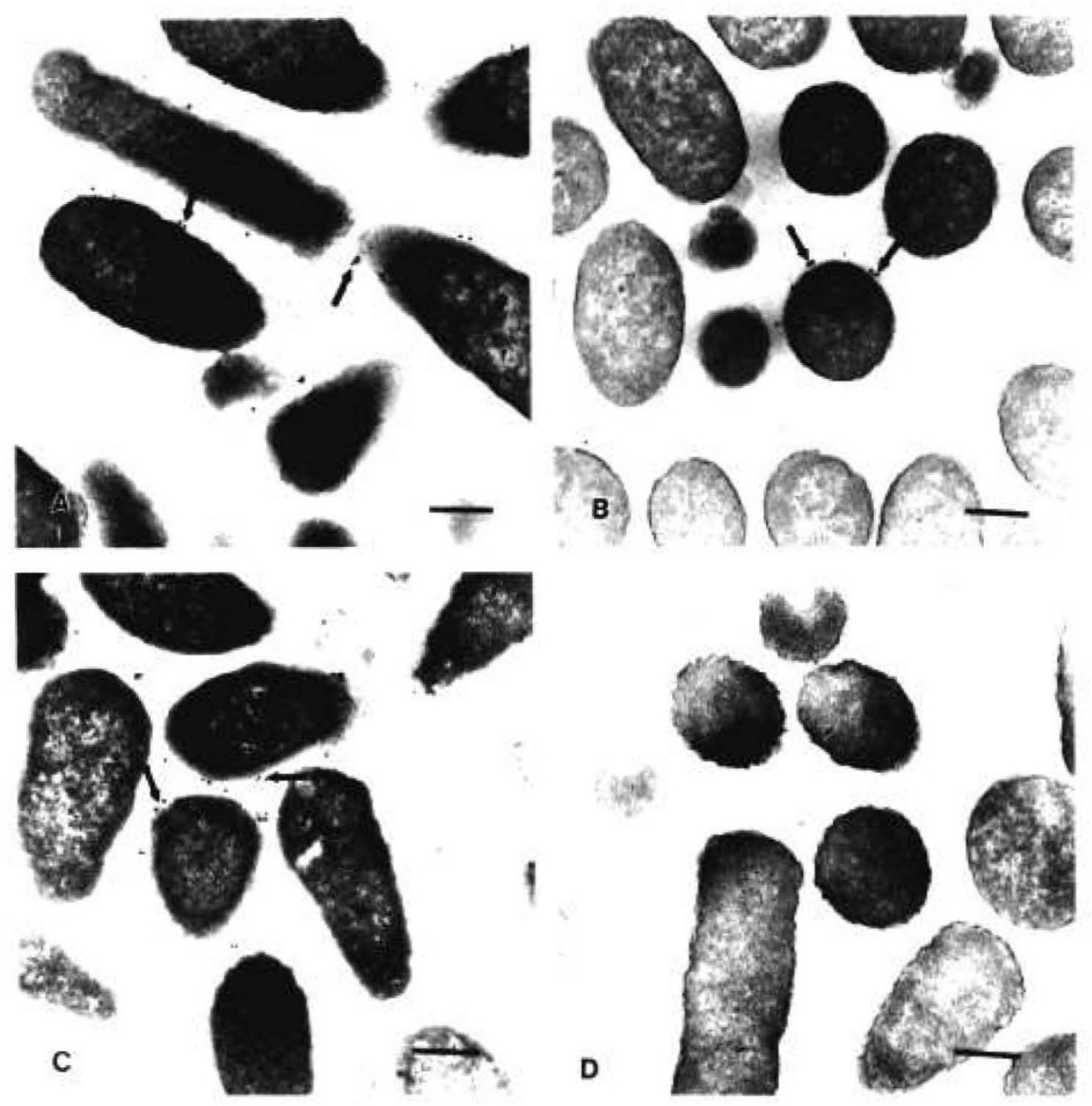

Fig. 4. Effect of supplemental C9 on the capacity of neonatal serum to deposit C9 onto E. coli. E. coli $\mathrm{O} 7 \mathrm{w}: \mathrm{K} 1: \mathrm{NM}$ were incubated with pooled adult serum $(A)$, pooled neonatal serum $(B)$, neonatal serum supplemented with $\mathrm{C} 9(C)$, and heat-treated neonatal serum supplemented with $C 9$ $(D)$. Arrows indicate the gold particles in the photomicrographs obtained after immunogold electron microscopy. Bar $=0.5 \mu \mathrm{m}$. Supplemental C 9 enhanced the capacity of neonatal serum to deposit $\mathrm{C} 9$ onto $E$. coli.

amounts of $\mathrm{C} 3$ were detected on the basis of a series of standards but represented less than $0.1 \%$ of the protein in the $C 9$ preparation. C5 was not detected and represented less than $0.2 \%$ of the protein in the $C 9$ preparation. SDS-PAGE analysis revealed that more than $90 \%$ of the protein in the solution was represented by a single band with an approximate molecular mass of $71000 \mathrm{D}$. Each of the minor bands detected by SDS-PAGE, including a band with a molecular mass of more than $180000 \mathrm{D}$, reacted with the anti-C 9 antiserum in the Western-blot assay. Therefore, the proteins detected by SDS-PAGE, other than monomeric C9, may represent aggregated $\mathrm{C} 9$ or $\mathrm{C} 9$ degradation products that developed during storage. The $\mathrm{C} 9$ was stored in $10-\mu \mathrm{L}$ aliquots at $-70^{\circ} \mathrm{C}$.

Quantitation of $C 9$ in serum by radial immunodiffusion. A radial immunodiffusion kit (Human C9 NL RID Kit) was purchased from The Binding Site. In duplicate, $5-\mu \mathrm{L}$ of serum was pipetted into the agar well, and the diameter of the immunoprecipitation ring was measured after $72 \mathrm{~h}$ of incubation at room temperature. The concentration of $\mathrm{C} 9$ was calculated from the regression equation derived from concurrent assays of control sera, provided by the vendor, which contained known concentrations of $\mathrm{C} 9$.

Antibodies. Affinity-purified, mouse monoclonal antihuman C9 antibody (Product No. 0947) was produced and supplied as a lyophilized powder by Accurate Chemical and Scientific Corporation (Westbury, NY). Morgan et al. $(16,17)$ demonstrated that this antibody binds to $\mathrm{C} 9$ that has been deposited onto biologic membranes and also to monomeric $\mathrm{C} 9$ in solution. The concentration of the anti-C 9 antibody was adjusted to $1 \mathrm{mg} / \mathrm{mL}$ in PBS. In some experiments, the anti-C9 antibody was labeled with ${ }^{125}$ I (Amersham, Arlington Heights, IL) using 1,3,4,6-tetrachloro-3 $\alpha, 6 \alpha$-diphenylglycouril (Sigma) by the method of Parker et al. (18). The radiolabeled antibodies (sp act, $8.8 \times 10^{5} \mathrm{cpm} /$ $\mu \mathrm{g}$ ) were dialyzed against three changes of PBS and stored at $4^{\circ} \mathrm{C}$. Protein concentrations were determined spectrophotometrically $(19,20)$.

Affinity-purified, colloidal gold-labeled goat antimouse IgG antibody was purchased from Energy Beam Sciences (Agalon, MA). The mean diameter of the gold particles was $15 \mathrm{~nm}$, and the antibody was supplied as a liquid formulation with an optical density of 4.0 at $520 \mathrm{~nm}$.

Bactericidal assay. E. coli isolate 1 (Table 1) was used to assess the effect of supplemental C9 on the kinetics of bacterial killing by neonatal serum. $E$. coli O7w:K1:NM $\left(1.6 \times 10^{4}\right.$ organisms suspended in $20 \mu \mathrm{L}$ of $\mathrm{BPBS}^{+}$) were incubated at $37^{\circ} \mathrm{C}$ for 90 min with $80 \mu \mathrm{L}$ of serum in reaction mixtures that contained a final volume of $200 \mu \mathrm{L}$. In some experiments, the mixtures were supplemented with $15 \mu \mathrm{g} \mathrm{C9}$. Also, some reaction mixtures were treated with $20 \mu \mathrm{L}$ of $100 \mathrm{mM}$ MgEGTA and were incubated 10 min at $37^{\circ} \mathrm{C}$ before the addition of the bacteria. In each case, the volume of the mixture was adjusted to $180 \mu \mathrm{L}$ with $\mathrm{BPBS}^{+}$before the addition of the bacteria.

Immediately after adding the bacteria and at 15 -min intervals during the incubation, $10 \mu \mathrm{L}$ of the mixture was removed and 


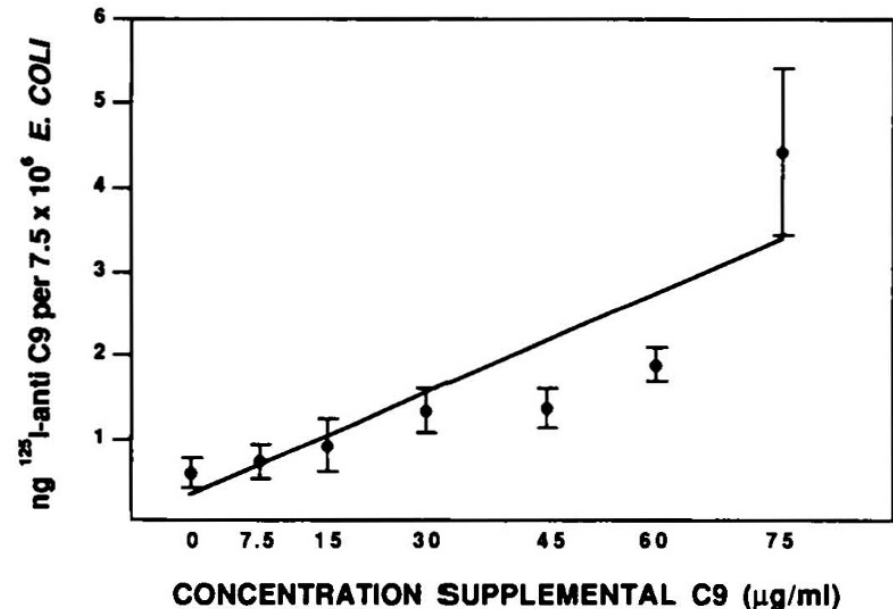

Fig. 5. Correlation between the concentration of supplemental C9 in neonatal serum and the quantity of $\mathrm{C} 9$ deposited onto $E$. coli. $E$. coli O7w:K1:NM were incubated with pooled neonatal serum containing various concentrations of supplemental $\mathrm{C} 9$. As determined by radiobinding assay, the results are depicted as the mean $( \pm S E)$ quantity of ${ }^{125} \mathrm{I}-$ labeled anti-C9 antibodies specifically bound to the bacteria $(n=3) . r=$ $0.88 ; p<0.01$. The quantity of $\mathrm{C} 9$ deposited onto the bacteria by the neonatal serum was positively correlated with the concentration of supplemental $\mathrm{C} 9$ in the serum.

diluted in $\mathrm{BPBS}^{+}$for quantitative culture in triplicate on tryptic soy agar by the pour-plate technique. The percentage of bacteria that survived was determined by dividing the number of colony forming units present at each 15 -min interval by the number originally present in the mixture. The assays, including concurrent control mixtures, were performed three times on separate days.

The bactericidal assay was modified to assess the effect of supplemental C9 on the capacity of neonatal serum to kill the eight different isolates of $E$. coli. Each isolate of bacteria $(8 \times$ $10^{3}$ organisms suspended in $10 \mu \mathrm{L}$ of $\mathrm{BPBS}^{++}$) was incubated with serum at $37^{\circ} \mathrm{C}$ for $120 \mathrm{~min}$. The quantity of serum used varied according to the experimental requirements (see below). Some mixtures containing neonatal serum were supplemented with $1 \mu \mathrm{g}$ of $\mathrm{C} 9$ per $5 \mu \mathrm{L}$ of serum. In each case, the volume of the mixture was adjusted to $90 \mu \mathrm{L}$ with BPBS $^{++}$before the addition of the bacteria. Immediately after adding the bacteria and at $20-\mathrm{min}$ intervals during the incubation, $10 \mu \mathrm{L}$ of the mixture was removed and diluted in $\mathrm{BPBS}^{++}$for quantitative culture in triplicate on tryptic soy agar.

Preliminary assays were conducted to determine the minimal concentration of adult serum required to kill each of the eight isolates of $E$. coli. Each isolate was incubated with various concentrations of adult serum for $90 \mathrm{~min}$, and the number of surviving bacteria were determined by quantitative culture. The $\mathrm{LC}_{90}$ was determined. The $\mathrm{LC}_{90}$ of the eight isolates ranged from 20 to $60 \%$ (Table 1 ).

To determine the effect of $\mathrm{C} 9$ on the survival of each isolate of $E$. coli, the concentration of serum used in the assay was equal to the $\mathrm{LC}_{90}$ of that particular isolate. For instance, the $\mathrm{LC}_{90}$ of $E$. coli isolate 1 was $20 \%$. Therefore, the concentration of adult and neonatal serum used in the reaction mixtures was $20 \%$.

Radiobinding assay. A radiobinding assay was developed to measure the quantity of $\mathrm{C} 9$ deposited onto the surface of $E$. coli during incubation with serum.

$E$. coli $\mathrm{O} 7 \mathrm{w}: \mathrm{K} 1: \mathrm{NM}$ (isolate $1 ; 8 \times 10^{7}$ organisms suspended in $20 \mu \mathrm{L}$ of $\mathrm{BPBS}^{+}$) were incubated at $37^{\circ} \mathrm{C}$ for 30 min with 80 $\mu \mathrm{L}$ of serum in reaction mixtures containing a final volume of $200 \mu \mathrm{L}$. In some experiments, the mixtures contained various quantities of supplemental C9. In each case, the final volume of the mixture was adjusted to $180 \mu \mathrm{L}$ with $\mathrm{BPBS}^{+}$before the addition of the organisms. Quantitative cultures in pilot experiments revealed that the concentration of bacteria did not change significantly during 30 min of incubation with adult serum or heat-treated adult serum under these experimental conditions. In contrast to the bactericidal assay, the radiobinding assay used a higher concentration of bacteria-4 $410^{8}$ rather than $8 \times 10^{5}$ organisms $/ \mathrm{mL}$ of reaction mixture.

In some experiments, the reaction mixtures contained $20 \mu \mathrm{L}$ of $100 \mathrm{mM}$ MgEGTA and were incubated $10 \mathrm{~min}$ at $37^{\circ} \mathrm{C}$ before the addition of the bacteria. A hemolytic assay using rabbit (21) and antibody-sensitized sheep red blood cells was used to verify that in pooled adult serum diluted to $40 \%$ with BPBS $+10 \mathrm{mM}$ MgEGTA blocked activation of the classic, but not the alternative, complement pathway (22). During incubation $\left(37^{\circ} \mathrm{C}, 30\right.$ min) with the adult serum but not heat-treated $\left(56^{\circ} \mathrm{C}, 30 \mathrm{~min}\right)$ adult serum, both rabbit and sheep red blood cells were completely lysed. However, during incubation with MgEGTA-treated adult serum, the rabbit cells but not the sensitized sheep cells were lysed.

After the incubation with serum, the bacteria were washed three times and resuspended in $400 \mu \mathrm{L}$ of BPBS $^{+}$. Next, in quintuplicate, $50 \mu \mathrm{L}$ ( $10^{7}$ organisms) were mixed with $50 \mu \mathrm{L}$ of PBS containing $1.5 \mu \mathrm{g}$ of radiolabeled anti-C9. Preliminary equilibrium binding experiments had previously demonstrated that this concentration of radiolabeled antibody was saturating. After incubation at $37^{\circ} \mathrm{C}$ for $30 \mathrm{~min}, 75 \mu \mathrm{L}$ of the mixture was layered over $200 \mu \mathrm{L}$ of phthalate oils (18) and centrifuged at $12000 \times g$ for $15 \mathrm{~min}$ at room temperature. Pilot studies using organisms labeled with ${ }^{125} \mathrm{I}$ had shown that more than $95 \%$ of the radioactivity associated with the bacteria was present in the cell pellet after centrifugation under the conditions described above. The cell-associated radioactivity was quantified with a gamma counter (RIASTAR model \#B5005, Packard Instruments, Downers Grove, IL).

The amount of anti-C9 antibody bound to the bacteria was calculated by using the specific activity of the radiolabeled ligand. The quantity of anti-C 9 antibody specifically bound during activation of the complement system was calculated by determining the radioactivity of the bacteria incubated with serum and subtracting the radioactivity of the bacteria incubated with heat-treated $\left(56^{\circ} \mathrm{C}, 30 \mathrm{~min}\right)$ serum. If the serum was supplemented with $\mathrm{C} 9$, the quantity of specifically bound anti-C9 antibody was calculated by determining the radioactivity of the bacteria incubated with $\mathrm{C} 9$-supplemented serum and subtracting the radioactivity of the bacteria incubated with C9-supplemented, heat-treated serum.

Immunogold electron microscopy. E. coli $\mathrm{O} 7 \mathrm{w}: \mathrm{K} 1: \mathrm{NM}$ ( $E$. coli isolate 1) were incubated with serum at $37^{\circ} \mathrm{C}$ for $30 \mathrm{~min}$. Each 500- $\mu \mathrm{L}$ mixture contained $200 \mu \mathrm{L}$ of serum and $50 \mu \mathrm{L}$ of $\mathrm{BPBS}^{+}$ containing $2 \times 10^{8}$ bacteria. Some mixtures contained $37.5 \mu \mathrm{g}$ of C9. The volume of the mixture was adjusted to $450 \mu \mathrm{L}$ with $\mathrm{BPBS}^{+}$before the addition of the bacteria. After the incubation, the organisms were washed three times and suspended in $100 \mu \mathrm{L}$ of $\mathrm{BPBS}^{+}$. Fifty microliters of the bacterial suspension $\left(1 \times 10^{8}\right.$ organisms) were incubated and gently rotated for $18 \mathrm{~h}$ at $4^{\circ} \mathrm{C}$ with $50 \mu \mathrm{L}$ of PBS containing $20 \mu \mathrm{g}$ of the anti-C9 MAb. Next, the bacteria were washed three times, suspended in $50 \mu \mathrm{L}$ of $\mathrm{BPBS}^{+}$, and incubated for $6 \mathrm{~h}$ at $4^{\circ} \mathrm{C}$ with $50 \mu \mathrm{L}$ of PBS containing $20 \mu \mathrm{g}$ of the colloidal gold-labeled antimouse IgG antibody. The organisms were then washed three times in BPBS ${ }^{+}$ and suspended in $2.5 \%$ glutaraldehyde. The bacteria were fixed in $1 \%$ osmium tetroxide, rapidly dehydrated with graded concentrations of ethanol, and embedded in LX-112 (Ladd, Burlington, VT). Thin sections were cut with an ultramicrotome, collected on copper grids, and doubly stained with uranyl acetate and Reynolds lead citrate. The cross-sectioned organisms were then visualized and photographed on a Philips CM-10 electron microscope.

The gold particles that bound to 100 bacteria were counted using the photomicrographs. The length of the bacterial surface 


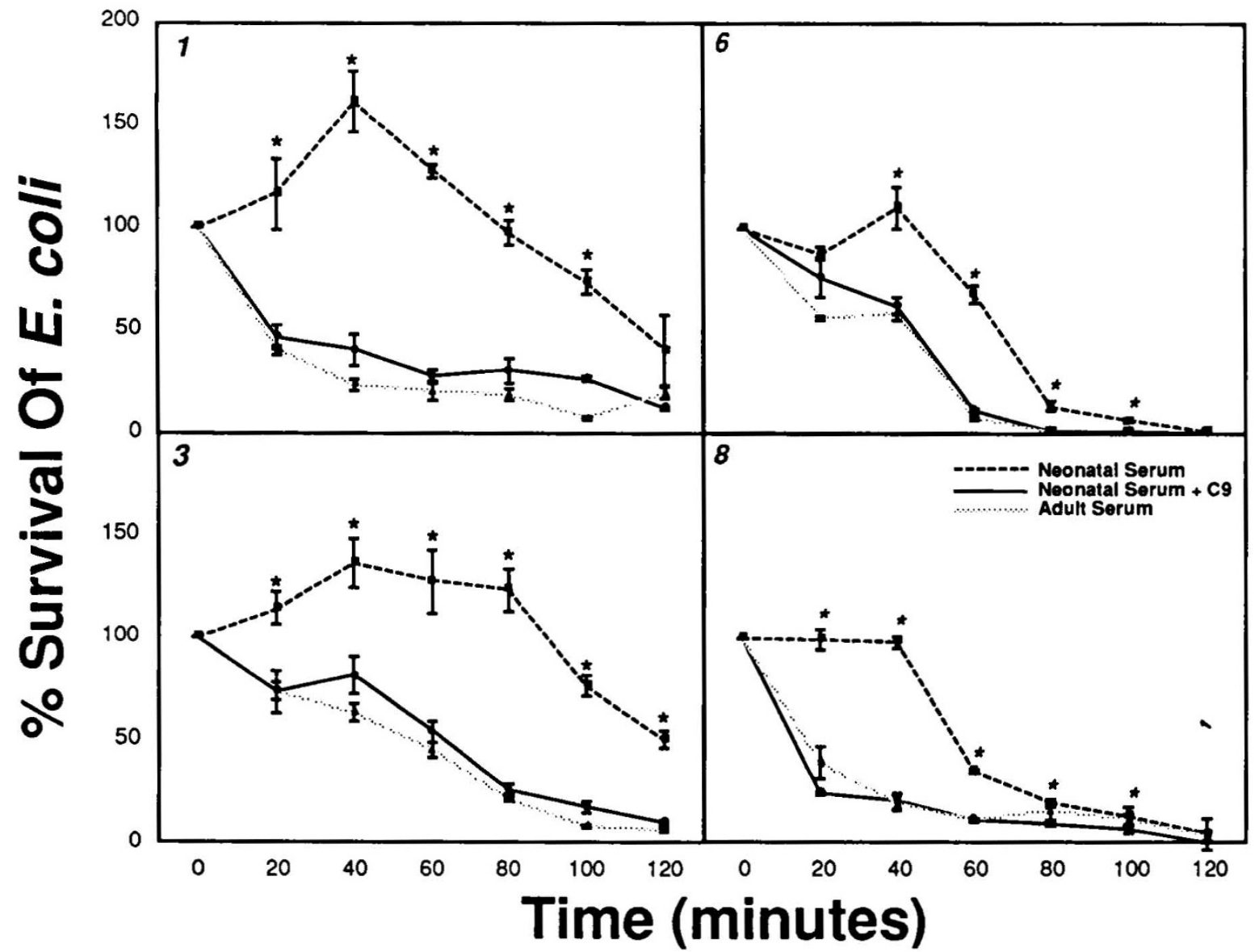

Fig. 6. Effect of supplemental C9 on the capacity of neonatal serum to kill four isolates of $E$. coli. Shown are representative experiments that analyzed isolates 1, 3, 6, and 8. Each isolate was incubated with pooled neonatal serum (broken lines), neonatal serum supplemented with C9 (solid lines), and pooled adult serum (stippled lines). As determined by bactericidal assay, the results are depicted as the mean bacterial survival \pm SE. *, $p<0.03$ vs neonatal serum supplemented with C9. The C9 supplemented serum, similar to adult serum, killed $E$. coli isolates 1 and 3 . Supplemental C 9 accelerated killing of isolates 6 and 8 by the neonatal serum.

visualized in cross section was measured by computer-assisted morphometric analysis with the Bioquant System 4 (R \& M Biometrics, Nashville, TN). The results were expressed as the number of gold particles bound per linear micrometer of bacterial surface. The number of gold particles specifically bound to the bacteria during activation of the complement system was calculated by subtracting the number of particles bound to the bacteria incubated in heat-treated control serum from the number of particles that bound to organisms incubated in serum not treated with heat. The assays for electron microscopy, including concurrent control mixtures, were performed three times on separate days.

Statistics. Correlations between continuous variables were determined by multiple linear regression analysis. Comparison of the means of continuous variables was performed with $t$ test for unpaired data.

For kinetic data derived from the bactericidal assays (Fig. 1), differences between groups were determined by repeated measures analysis and Bonferroni simultaneous $t$ tests (23). Nonlinear differences were compared with full model-reduced model test using indicator variables $(24,25)$.

\section{RESULTS}

Serum concentrations of $C 9$. The concentration of $\mathrm{C} 9$ in serum pooled from the adults was $211.5 \mathrm{mg} / \mathrm{L}$. In contrast, the $\mathrm{C} 9$ concentration in sera from 10 neonates was $23.6 \pm 4.0 \mathrm{mg} / \mathrm{L}$ (mean $\pm \mathrm{SEM}$; range, $8.4-34.7 \mathrm{mg} / \mathrm{L}$ ). In the serum pooled from 20 neonates, the $\mathrm{C} 9$ concentration was $25.5 \mathrm{mg} / \mathrm{L}$.

Effect of supplemental C 9 on the kinetics of bacterial killing by neonatal serum. Both pooled adult serum and pooled neonatal serum killed $E$. coli $\mathrm{O} 7 \mathrm{w}: \mathrm{K} 1: \mathrm{NM}$. In pooled adult serum, a reduction in the number of surviving bacteria was detectable at $15 \mathrm{~min}$ of incubation. In contrast, in the pooled neonatal serum, a reduction in the number of surviving bacteria was not detectable until the organisms had incubated for $60 \mathrm{~min}$. During incubation of $E$. coli in pooled neonatal serum that had been supplemented with $\mathrm{C} 9(75 \mathrm{mg} / \mathrm{L})$, the time required to detect a reduction in the bacterial count and the rate of decline in the number of surviving bacteria was indistinguishable from that observed in the pooled adult serum (Fig. 1). The number of surviving bacteria did not change significantly during incubation with $\mathrm{BPBS}^{+}$or with $\mathrm{BPBS}^{+}$supplemented with $\mathrm{C} 9$ in the absence of serum. The bacteria proliferated during incubation with adult serum, neonatal serum, or C9-supplemented neonatal serum treated with heat $\left(56^{\circ} \mathrm{C}, 30 \mathrm{~min}\right)$ or MgEGTA.

Deposition of $C 9$ onto $E$. coli by neonatal serum. During incubation of $E$. coli $\mathrm{O} 7 \mathrm{w}: \mathrm{K} 1: \mathrm{NM}$ with pooled adult serum, C9 was specifically deposited onto the bacteria. However, during incubation with each of the neonatal sera (Fig. 2) or with the pooled neonatal serum (Fig. 3), the quantity of C9 that was deposited onto the bacteria was diminished compared with that observed in adult serum. The quantities of $\mathrm{C} 9$ deposited onto the organisms by the 10 individual neonatal sera were not 
correlated with the concentrations of $\mathrm{C} 9$ in these sera (data not shown; $r=0.20, p=0.58$ ).

Effect of supplemental C9 on the deposition of C9 onto E. coli by neonatal serum. $\mathrm{C} 9$ deposition onto the surface of $E$. coli O7w:K1:NM during incubation with $40 \%$ serum was quantified by the radiobinding assay and by immunogold electron microscopy. During incubation of $E$. coli with pooled neonatal serum that had been supplemented with $\mathrm{C} 9(75 \mu \mathrm{g} / \mathrm{mL})$, the quantity of $\mathrm{C} 9$ deposited onto the organisms was increased to an amount equivalent to that observed in adult serum (Fig. 3). MgEGTA impaired the deposition of $\mathrm{C} 9$ during incubation of the bacteria with pooled adult serum or with C9-supplemented, pooled neonatal serum.

Electron microscopy revealed that the number of gold particles that specifically bound to each linear micrometer of bacterial surface was as follows: 1 ) after incubation with adult serum, 0.93 $\pm 0.2 ; 2)$ after incubation with neonatal serum, $0.30 \pm 0.1(p<$ 0.01 versus adult serum); and 3 ) after incubation with neonatal serum supplemented with $C 9,1.39 \pm 0.3(p<0.01$ versus unsupplemented neonatal serum). Only 0.055 gold particles $/ \mu \mathrm{m}$ were detected on the surface of bacteria incubated in heat-treated adult serum. Gold particles were not detected on the surface of bacteria incubated in heat-treated neonatal serum, in heat-treated neonatal serum supplemented with $\mathrm{C} 9$, in $\mathrm{C} 9$ and buffer in the absence of serum, or in buffer without serum or C9 (Fig. 4).

In separate experiments, $\mathrm{C} 9$ deposition was quantified on $E$. coli that were incubated with pooled neonatal serum supplemented with various quantities of $C 9$ (the concentration of supplemental C9 ranged from 0 to $75 \mu \mathrm{g} / \mathrm{mL}$ of reaction mixture). The quantity of $\mathrm{C} 9$ deposited onto the bacteria by the pooled neonatal serum was positively correlated with the concentration of supplemental C9 in the reaction mixture (Fig. 5).

Effect of supplemental $C 9$ on the capacity of neonatal serum to kill eight isolates of $E$. coli. Adult serum killed all eight isolates of $E$. coli. Bacterial killing was defined as a reduction in bacterial survival to less than $20 \%$ of the original inoculum during 120 min of incubation. However, after $120 \mathrm{~min}$ of incubation of neonatal serum with $E$. coli isolates 1 through 4 , more than $20 \%$ of the original inoculum survived (Fig. 6). In contrast, the C9supplemented neonatal serum, like the adult serum, killed each of these four isolates. In each case, the number of surviving bacteria was reduced more rapidly during incubation with the C9-supplemented serum than with neonatal serum that was not supplemented with $\mathrm{C} 9$.

Neonatal serum killed isolates 5 through 8 . However, the rate of bacterial killing in the neonatal serum was accelerated by supplemental C9 (Fig. 6). In the neonatal serum, isolates 5 through 8 were killed within $85 \pm 5$ min (mean $\pm S E M$ ). In contrast, in the C9-supplemented neonatal serum, these four isolates were killed within $50 \pm 13 \mathrm{~min}(p<0.05$ versus unsupplemented neonatal serum).

Each of the eight isolates of $E$. coli proliferated during incubation with heat-treated $\left(56^{\circ} \mathrm{C}\right.$ for $\left.30 \mathrm{~min}\right)$ adult serum, heattreated neonatal serum, heat-treated neonatal serum supplemented with $\mathrm{C} 9, \mathrm{C} 9$ and buffer in the absence of serum, and in buffer without serum or $\mathrm{C} 9$.

\section{DISCUSSION}

Previous studies determined that, compared with adults, neonatal serum killed an isolate of $E$. coli inefficiently. This observation was due at least in part to diminished concentrations of C9 in the sera of neonates $(7,12)$. The studies reported herein revealed that the onset of a detectable decline in the number of surviving bacteria was delayed during incubation with pooled neonatal serum (Figs. 1 and 6). After supplementation of the neonatal serum with $\mathrm{C} 9$, the time of onset and the rate of bacterial killing were indistinguishable from that observed in adult serum. These findings suggest that 1 ) the diminished $C 9$ concentration retarded the onset and rate of bacterial killing and
2) the pooled neonatal serum contained sufficient quantities of the complement components, other than $\mathrm{C} 9$, required to kill $E$. coli at a rate similar to that observed in adult serum.

Although some isolates of $E$. coli are slowly killed in C9deficient serum, C9 is required for efficient bactericidal activity of adult serum against $E$. coli $(9,10,26-31)$. During complement-mediated cytolysis, the proteins $\mathrm{C} 5, \mathrm{C} 6, \mathrm{C} 7$, and $\mathrm{C} 8$ are sequentially assembled on the cell surface to form C5b-8 complexes that insert into the cell membrane $(9,27,28)$. Complete membrane attack complexes are formed when the C $5 \mathrm{~b}-8 \mathrm{com}$ plexes bind several molecules of $\mathrm{C} 9$, which polymerize to form large membrane channels that may result in cell injury, death, and lysis $(31-36)$.

Supplemental $\mathrm{C} 9$ has been shown to increase the rate of killing of a laboratory strain of $E$. coli by serum from a C9-deficient adult (10). With a pathogenic isolate of $E$. coli (serotype O7w:K1:NM), this phenomenon is now reported in the serum of healthy neonates (Fig. 1). However, unsupplemented $40 \%$ neonatal serum did kill the bacteria, albeit slowly compared with serum from healthy adults. Possibly, the isolate of $E$. coli used was an isolate that is killed slowly by serum in the absence of $C 9$ by the assembly and deposition of $\mathrm{C} 5 \mathrm{~b}-8$ complexes on the bacterial surface. Alternatively, $\mathrm{C} 9$ may have been required to kill the bacteria, but the diminished concentration of $\mathrm{C} 9$ in the neonatal serum may have limited the number of $\mathrm{C} 9$ molecules incorporated into each membrane attack complex or retarded the assembly of the complexes. After supplementation with C9, pooled neonatal serum killed $E$. coli as rapidly as the adult serum. These results suggest that the bactericidal activity of the neonatal serum was restricted by the concentration, rather than activation, of $\mathrm{C} 9$.

To determine the mechanisms by which supplemental C9 accelerates bacterial killing in neonatal serum, we used a radiobinding assay and immunogold electron microscopy. Previous studies revealed that radiolabeled supplemental C 9 was deposited onto $E$. coli by neonatal serum (12). However, these studies did not determine whether the supplemental $C 9$ was displacing intrinsic $\mathrm{C} 9$ from the bacterial surface or whether the total amount of C9 deposited was enhanced. The studies reported herein revealed that, compared with adult serum, neonatal serum deposited a diminished quantity of $C 9$ onto $E$. coli. Supplemental C9 increased the total quantity of $\mathrm{C} 9$ deposited onto the organisms by neonatal serum to a level that equaled or exceeded that observed in adult serum. The quantity of C 9 deposited by the neonatal serum was dependent on the quantity of supplemental C9 provided. C9 deposition was abolished by treatment of serum by heat or MgEGTA. MgEGTA blocks activation of the classic pathway of complement but leaves the alternative pathway intact (22). Hence, complement-mediated killing of $E$. coli O7w:K1:NM by serum required activation of the classic pathway. Therefore, supplemental C9 enhanced the bactericidal activity of neonatal serum by increasing the deposition of $C 9$ onto $E$. coli mediated by activation of the classic pathway of complement. Furthermore, the results suggest that the pooled neonatal serum contained sufficient quantities of the other components of the classic pathway to kill the bacteria rapidly if sufficient exogenous C9 was provided. However, the results do not exclude the possibility that other factors, such as antibody-deficiency or diminished complement components in addition to C9, may also contribute to inefficient serum bactericidal activity in the sera of individual neonates.

In the sera of individual neonates, the quantity of $\mathrm{C} 9$ deposited onto $E$. coli was variable and was unrelated to the concentration of intrinsic C9. This observation is consistent with previous experiments that revealed that the survival of $E$. coli in the sera of individual neonates was variable (12). These prior studies also revealed that the effect of supplemental $C 9$ on the bactericidal activity of neonatal sera was variable and was potentiated by supplemental IgG that contained anti- $E$. coli antibodies. In most cases, the $C 9$ supplementation reduced the survival of $E$. coli 
incubated with sera from individual neonates, but the bacteria were not killed (12). Taken together, the prior and present studies suggest that the sera of some individual neonates may contain not only diminished concentrations of $\mathrm{C} 9$ but also diminished activity of the other components of serum required to deposit $C 9$ onto $E$. coli and to kill the bacteria, such as anti-E. coli antibodies or components of the classic pathway of complement.

Eight pathogenic isolates of $E$. coli were incubated with serum pooled from 20 neonates. The serum contained IgG antibodies transferred from the blood of their mothers. This experimental design diminished the probability that a deficiency of $E$. coli antibodies would confound the assessment of the effect of supplemental C9 in neonatal serum. Supplemental C9 enhanced the capacity of pooled neonatal serum to kill each of the bacterial isolates. The results were consistent with the theory that a diminished concentration of $\mathrm{C} 9$ contributes to the bacteriolytic defect observed in neonatal serum. The results also indicated that several different isolates of $E$. coli that cause sepsis in neonates were killed inefficiently by serum from neonates compared with adults. Furthermore, the resistance to rapid bacteriolysis manifested by the various isolates during incubation with pooled neonatal serum was due, at least in part, to a diminished serum concentration of $\mathrm{C} 9$.

The clinical consequences of diminished $\mathrm{C} 9$ serum concentrations in newborn infants are not clear. Previous studies revealed that the isolates of $E$. coli obtained from the blood of septic neonates were predominantly serum sensitive (killed during incubation with serum from healthy adults) (7). The studies reported herein revealed that supplemental $C 9$ enhanced the bactericidal capacity of neonatal serum to kill several isolates of pathogenic bacteria. Taken together, the studies suggest that a diminished concentration of $C 9$ may possibly be one of the defects in host immunity that predispose neonates to invasion by serum sensitive isolates of $E$. coli.

Unlike neonates, C9-deficient adults have not been shown to be predisposed to invasion by $E$. coli (37). However, the immune system of newborn infants, unlike C9-deficient adults, is characterized by multiple deficiencies, such as reduced serum concentrations of various complement components, variable serum concentrations of anti- $E$. coli antibodies, and diminished function and quantity of neutrophils $(11,38-41)$. Therefore, it is possible that $\mathrm{C} 9$ deficiency is one of several immune defects that. in combination, predispose neonates to the acquisition of $E$. coli sepsis.

In summary, compared with adult serum, neonatal serum deposited a diminished quantity of $\mathrm{C} 9$ onto $E$. coli and killed the bacteria inefficiently. Supplementation of neonatal serum with $\mathrm{C} 9$ accelerated the onset and rate of bacterial killing, increased the total quantity of $\mathrm{C} 9$ deposited onto the surface of $E$. coli, and enhanced the bactericidal activity against eight different pathogenic isolates of $E$. coli. Therefore, $\mathrm{C} 9$ deficiency restricted the capacity of neonatal serum to deposit $\mathrm{C} 9$ and to kill bacteria. C9 deficiency may possibly be one of the defects in antibacterial host defense that predisposes neonates to the acquisition of $E$. coli sepsis. However, the role of $\mathrm{C} 9$ deficiency in the pathogenesis of $E$. coli sepsis in human neonates remains speculative and will require assessment with continued investigation, such as the development of an animal model.

\section{REFERENCES}

1. Klein JO, Marcy SM 1990 Bacterial sepsis and meningitis. In: Remington JS Klein JO (eds) Infectious Diseases of the Fetus and Newborn Infant. 3rd Ed. WB Saunders, Philadelphia. pp 601-656

2. Gladstone IM, Ehrenkranz RA. Edberg SC, Baltimore RS 1990 A ten-year review of neonatal sepsis and comparison with the previous fifty-year experience. Pediatr Infect Dis J 9:819-825

3. Roantree RJ, Rantz LA 1960 A study of the relationship of the normal bactericidal activity of human serum to bacterial infection. J Clin Invest 39:72-81

4. Vosti KI. Randall E 1970 Sensitivity of serologically classified strains of
Escherichia coli of human origin to the serum bactericidal system. Am J Med Sci 259:114-119

5. Fierer J, Finley F, Braude AI 1972 A plaque assay on agar for detection of gram negative bacilli sensitive to complement. J Immunol 109:1156-1158

6. Gitlin D, Rosen FS, Michael JG 1963 Transient 19 S gamma-globulin deficiency in the newborn infant, and its significance. Pediatrics 33:197-208

7. Lassiter HA. Tanner JE, Miller RD 1992 Inefficient bacteriolysis of Escherichia coli by serum from human neonates. J Infect Dis 165:290-298

8. Taylor PW 1983 Bactericidal and bacteriolytic activity of serum against gramnegative bacteria. Microbiol Rev 47:46-83

9. Joiner KA, Schmetz MA, Sanders ME, Murray TG, Hammer CH, Dourmashkin R, Frank MM 1985 Multimeric complement component $C 9$ is necessary for killing of Escherichia coli J5 by terminal attack complex C5b-9. Proc Natl Acad Sci USA 82:4808-4812

10. Pramoonjago P. Kinoshita T, Hong K. Taktakazono Y, Kozono H, Inagj R. Inoue K 1992 Bactericidal activity of C9-deficient human serum. J Immunol 148:837-843

11. Ballow M, Fang F, Good RA, Day NK 1974 Developmental aspects of complement components in the newborn: the presence of complement components and $\mathrm{C} 3$ proactivator (properdin factor B) in human colostrum. Clin Exp Immunol 18:257-266

12. Lassiter HA, Watson SW, Seifring ML, Tanner JE 1992 Complement factor 9 deficiency in the serum of human neonates. J Infect Dis 166:53-57

13. Mancini G. Carbonara AO. Heremans JF 1965 Immunochemical quantification of antigens by single radial immunodiffusion. Immunochemistry 2:235254

14. Biesecker G. Müller-Eberhard HJ 1980 The ninth component of complement: purification and physiochemical characterization. J Immunol 124:12911296

15. Matsudaria $P(987$ Sequence from picomole quantities of proteins electroblotted onto polyvinylidene difluoride membranes. J Biol Chem 262:1003510038

16. Morgan BP. Sewry CA. Siddle K. Luzio JP. Campbell AK 1984 Immunolocalization of complement component $\mathrm{C} 9$ on necrotic and non-necrotic muscle fibres in myositis using monoclonal antibodies: a primary role of complement in autoimmune damage. Immunol 52:181-188

17. Morgan BP. Daw RA. Siddle K, Luzio JP. Campbell AK 1983 Immunoaffinity purification of human complement component $\mathrm{C} 9$ using monoclonal antibodies. J Immunol Methods 64:269-281

18. Parker CJ, Baker PJ, Rosse WF 1983 Comparison of binding characteristics of factors $\mathrm{B}$ and $\mathrm{H}$ to $\mathrm{C} 3 \mathrm{~b}$ on normal and paroxysmal nocturnal hemoglobinuria erythrocytes. J Immunol 131:2484-2489

19. Layne E 1957 Spectrophotometric and turbidimetric methods for measuring proteins. Methods Enzymol 3:447-454

20. Parker CJ, Soldato CM, Telen MJ 1984 Increased efficiency of binding of nascent $\mathrm{C} 3 \mathrm{~b}$ to the erythrocytes of chronic cold agslutinin disease. J Clin Invest 74:1050-1062

21. Platts-Mills TAE. Ishizaka K 1974 Activation of the alternative pathway of human complement by rabbit cells. J Immunol 113:348-357

22. Des Pres RM. Bryan CS. Hawiger J, Colley DG 1975 Function of the classical and alternate pathways of human complement in serum treated with ethylene glycol tetraacetic acid and $\mathrm{MgCl}_{2}$-ethylene glycol tetraacetic acid. Infect Immun 11:1235-1243

23. Milliken G, Johnson D 1984 Analysis of Messy Data. Vol I. Van Nostrand Reinhold Co, New York

24. Neter J. Wasserman W. Kutner M 1983 Applied Linear Regression Models. Richard D. Irwin. Inc, Homewood, IL

25. Gallant AR 1987 Nonlinear Statistical Models. John Wiley and Sons, New York

26. Goldman NJ, Ruddy S, Austen KF. Feingold DS 1969 The serum bactericidal reaction. III. Antibody and complement requirements for killing of a rough form of Escherichia coli. J Immunol 102:1379-1387

27. Kolb WP. Haxby JA, Arroyave CM, Müller-Eberhard HJ 1972 Molecular analysis of the membrane attack complex of complement. J Exp Med 135:549-566

28. Goldman NJ. Austen KF 1974 Reaction mechanisms of the nascent C 567 (reactive lysis). II. Killing of a rough form of Escherichia coli by C567, C8, and C9. J Infect Dis 129:444-450

29. Kolb WP, Müller-Eberhard HJ 1976 The membrane attack mechanism of complement: the three polypeptide chain structure of the eighth component (C8). J Exp Med 143:1131-1139

30. Bhakdi S, Kuller G, Muhly M. Fromm S. Seibert G. Parrisius J 1987 Formation of transmural complement pores in serum-sensitive Escherichia coli. Infect Immun 55:206-210

31. MacKay SL. Dankert JR 1990 Bacterial killing and inhibition of inner membrane activity by C 5 b- 9 complexes as a function of the sequential addition of $\mathrm{C} 9$ to C5b-8 sites. J Immunol 145:3367-3371

32. Kolb WP. Müller-Eberhard HJ 1974 Mode of action of C9: adsorption of multiple molecules to cell-bound C8. J Immunol 113:479-488

33. Podack ER. Tschoop J, Müller-Eberhard HJ 1982 Molecular organization of 
C9 within the membrane attack complex of complement: induction of circular C9 polymerization by the CSb-8 assembly. J Exp Med 156:268-282

34. Podack ER 1984 Molecular composition of the tubular structure of the membrane attach complex of complement. J Biol Chem 259:8641-8647

35. Tschopp J, Podack ER, Müller-Eberhard HJ 1982 Ultrastructure of the membrane attack complex of complement: detection of the tetramolecular C9polymerizing complex C5b-8. Proc Natl Acad Sci USA 79:7474-7478

36. Zalman LS, Müller-Eberhard HJ 1990 Comparison of channels formed by poly $\mathrm{C} 9, \mathrm{C} 5 \mathrm{~b}-8$ and the membrane attack complex of complement. Mol Immunol 27:533-537

37. Lint TF, Gewurz H 1986 Complement deficiencies 9. The ninth component. Progr Allergy 39:307-310

38. Christensen RD, Macfarlane JL, Taylor NL, Hill HR, Rothstein G 1982 Blood and marrow neutrophils during experimental group B streptococcal infection: quantification of the stem cell, proliferative, storage and circulating pools. Pediatr Res 16:549-553

39. Miller ME 1989 Immunodeficiencies of immaturity. In: Stiehm ER (ed) Immunologic Disorders in Infants and Children. 3rd Ed. WB Saunders, Philadelphia, pp 196-225

40. Sennhauser FH, Balloch A, Macdonald RA, Shelton MJ, Roberton DM 1990 Maternofetal transfer of $\operatorname{lgG}$ anti-Escherichia coli antibodies with enhanced avidity and opsonic activity in very premature neonates. Pediatr Res 27:365371

41. Wilson CB 1990 Developmental immunology and role of host defenses in neonatal susceptibility. In: Remington JS, Klein JO (eds) Infectious Diseases of the Fetus and Newborn Infant. 3rd Ed. WB Saunders, Philadelphia, pp $17-67$

\section{Announcement}

The Stable Isotopes in Nutritional and Metabolic Research 2nd World Conference will be held July 7-8, 1994 at the Erasmus Expo and Conference Centre, Erasmus University Rotterdam, the Netherlands. For further information, please contact: Erasmus Forum, Erasmus University Rotterdam, P.O. Box 1738, NL-3000 DR Rotterdam, phone $+31.10 .408 .23 .02 / 10.98$, fax +31.10 .453 .07 .84 . 